\title{
急ぎ・焦りェラーに関する体験型教育の効果
}

\author{
○森泉 慎吾, 臼井 伸之介 (大阪大学 大学院人間科学研究科) \\ 和田 一成, 上田 真由子（西日本旅客鉄道株式会社安全研究所）
}

\section{Effect of experience-based safety education about human errors triggered by urgency}

\author{
Shingo MORIIZUMI, Shinnosuke USUI (Graduate school of Human sciences, Osaka University), \\ Kazushige WADA, Mayuko UEDA (Safety Research Institute, West Japan Railway Company)
}

\section{1. 研究背景と目的}

緊急時に生じる「急ぎ・焦り」の心理は, ヒューマンエラーの生起頻度を高めることが知ら れている1)。しかし，そのような急ぎ・焦りエ ラーのメカニズムおよび対策を効果的に教育する ことは，ヒューマンエラーが非意図的な行動であ るがゆえに容易ではない。近年では，エラ一防止 に関する介入策の一つとして，体験型の安全教育 が注目されており，その中で眠井尘は，不安全行 動やその背景にある人間心理をPCベースで体験・ 理解可能な「エラー体験プログラム」を開発し, その教育効果を確認している ${ }^{3)}$. 本研究において は，エラー体験プログラム「急ぎ・焦り体験」の 教育効果およびその持続性について実験的に検証 することを目的とした。

\section{2. 方法}

\section{2-1. 参加者}

人材派遣会社を通じて募集された 20 代と 40 代の 男女81名（男性40名，女性41名）が参加した。平

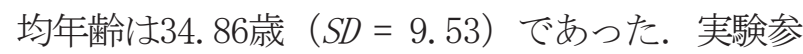
加の謝金として 3,000 円が支払われた。教育群に 40名，統制群（教育なし）に41名を割り当てた. なお本研究は，大阪大学大学院人間科学研究科行 動学系倫理審査委員会の承認を得て実施した。

$2-2$. 実施した安全教育

「急ぎ・焦り」に関する安全教育として「エ ラー体験プログラム」 ${ }^{2-3)}$ のうち「急ぎ・焦り体 験」を実施した．本プログラムでは，急ぎ・焦り による人間のパフォーマンス低下を体験から理解 することを趣旨としていた，参加者は，制限時間 「あり」条件 (80秒) と「なし」条件の下で，水 道管課題（画面に提示される水道管回路のスイッ
チをマウスクリックで回転させ，特定のゴールに 向けて水路を変える課題）を実施し，特に「あ り」条件での成績低下を体験した（課題の詳細に ついては引用文献1）を参照のこと）。課題では, 全ての参加者が制限時間「なし」，「あり」の順番 で課題を体験した。制限時間「あり」条件では, 制限時間がカウントダウンで表示され，制限時間 に近づくと画面両端に位置するラインの点滅とと もにビープ音が提示された。 なお，課題はゴール までに最低限必要なクリック数によって難易度 （低／高）が操作され，全ての参加者が難易度 「低」,「高」の順番で課題を実施した。体験後, 急ぎや焦り状態とヒューマンエラーとの関係につ いての解説とともに，それらに関する実際の事故 事例が提示された。体験の所要時間は説明を含め て約40分であった。なお，統制群の参加者には,

「急ぎ・焦り」と直接関係しない単純な認知課題 等を実施した。

\section{$2-3$. 教育効果の評価}

急ぎ焦りに関する日常での不安全行動（例. 車 や自転車を運転中，急いでいると，一旦停止をお ろそかにしてしまう）や態度（例. 焦っていても， 普段通りの力が発揮できると思う）について計5 項目尋ねた。いずれも5件法（1＝全く当てはま らない〜 $5=$ 非常に当てはまる）にて評定され た. 測定は，体験（課題）の前（Time 1), 直後 (Time 2)，1か月後（Time 3）の計3回なされた. なお，Time 3での測定については，実験終了の約 1か月後を目途に参加者にメールにて追加調査の 案内を送付し, Web形式にて質問項目への回答を 求めた.

$2-4$. デザイン

群 (教育群 / 統制群)，測定時期（Time 1／ Time 2/Time 3）の2要因混合計画であった。 


\section{3. 結果}

全ての測定時期のデータの得られた 63 名 （77. 8\%）を分析対象とした. 分析においては, 急ぎ・焦りに関する「態度」については構成 する項目の平均を得点として用いた（ $a$ $=.69 \sim .80)$. 「不安全行動」については各項 目の合成後の $\alpha$ 係数が低かったため, 項目ご とに分析を行った，下記の図表は，各測定時 期における群別の急ぎ・焦りに関する不安全 行動 3 種 (表) および態度 (図) の評定平均 である. 不安全行動については, 教育群・統 制群ともに時期による大きな変化は認められ ないが，態度については，特に教育群につい て Time 1 から Time 3 にかけての值の減少, すなわち安全側に変容していることが窥える. これら 4 変数を従属変数とし, 群と測定時期 を独立変数とした 2 要因分散分析を実施した. その結果, 不安全行動については, いずれの 項目においても群, 測定時期の主効果および 交互作用は確認されなかった。態度について は, 群の主効果が有意であり $(F(1,61)=$ 6. 22, $\left.p<.05, \eta_{p}^{2}=.09\right)$, 統制群よりも教 表 教育の有無による不安全行動の変化

\begin{tabular}{|c|c|c|c|c|}
\hline \multirow{2}{*}{$\begin{array}{l}\text { 不安全行動に関する } \\
\text { 質問項目 }\end{array}$} & & \multicolumn{3}{|c|}{ 測定時期 } \\
\hline & & Time 1 & Time 2 & Time 3 \\
\hline \multirow{2}{*}{$\begin{array}{l}\text { *周囲からせかされて } \\
\text { も、慌てずに振る舞える }\end{array}$} & 教育群 & $3.23(1.06)$ & $3.36(0.98)$ & $3.32(0.91)$ \\
\hline & 統制群 & $2.94(1.05)$ & $2.91(1.17)$ & $2.91(1.03)$ \\
\hline \multirow{2}{*}{$\begin{array}{l}\text { 車や自転車を運転中、 } \\
\text { 急いでいると、旦停止 } \\
\text { をおろそかにしてしまう }\end{array}$} & 教育群 & $2.55(1.31)$ & $2.58(1.29)$ & $2.65(1.14)$ \\
\hline & 統制群 & $2.94(1.27)$ & $2.97(1.28)$ & $2.75(1.27)$ \\
\hline \multirow{2}{*}{$\begin{array}{l}\text { 仕事の遅い人がいる } \\
\text { と、急がせてしまう }\end{array}$} & 教育群 & $2.97(1.05)$ & $2.81(1.11)$ & $2.81(1.05)$ \\
\hline & 統制群 & $2.72(0.99)$ & 2.591 .10 & $2.94(0.88)$ \\
\hline
\end{tabular}

注)*は逆転項目

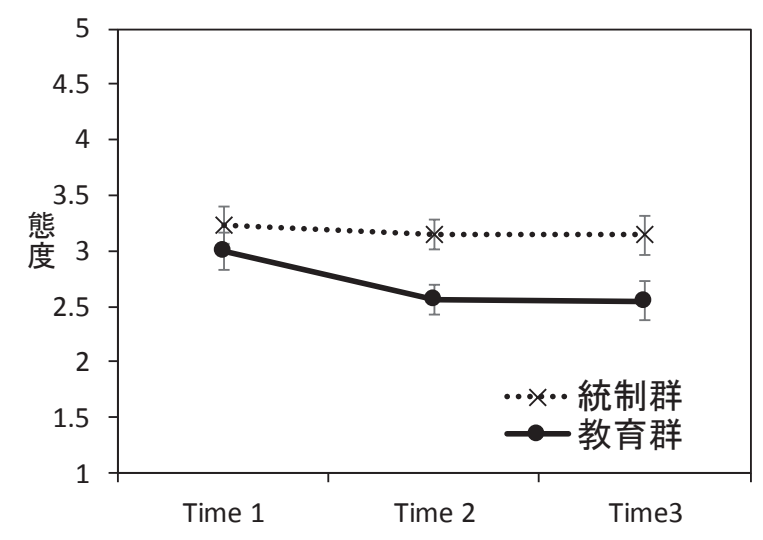

図教育の有無による態度の変化 ※エラーバーは標準誤差
育群の態度の評定平均が低かった。また測定 時期の主効果が有意であり（F（1.31，79.68） $=4.03, \quad p<.05, \quad \eta_{p}^{2}=.06$ : Greenhouse Geisser の $\varepsilon$ にて自由度を補正), Bonferroni 法による多重比較の結果, Time 1 よりも Time 2 の態度の評定平均が低かった（ $p<.05 ）$.

Time 1 と Time 3, およびTime 2 と Time 3 の 間の得点差はそれぞれ非有意であった．群と 測定時期の交互作用についても非有意であつ た $(F(2,122)=1.71, p=.19)$.

\section{4. 考察}

本研究にて，急ぎ・焦りエラーに対する安 全教育「エラー体験プログラム : 急ぎ・焦り 体験」を実施した結果，特に「態度」の側面 について統制群よりも教育群の得点が低く なった。これは，教育目的である「急ぎ・焦 りによる人間のパフォーマンス低下」をより 理解できたことを意味する，特に，図から読 み取れる通り, 教育直後の Time 2 と 1 か月後 の Time 3 において統制群と比較して教育群の 態度の得点が低く, 教育効果の持続が示唆さ れる．以上の点より，本プログラムがヒュー マンエラー防止教育のツールとして有効であ るといえる.今回の研究では, 自らの体験の 結果や事故事例の紹介から，急ぎ・焦りに よって人間の心理や行動が「不安全になる」 点を学習したのみであり, その後の対策につ いての教育が不十分であった，そのため，「不 安全行動」の側面にて変容が見られなかった 可能性がある.今後は, 教育後にグループ ディスカッションを設けるなど, 急ぎ・焦り エラーの具体的な防止策について参加者自身 が考える機会を設ける必要がある。

\section{5. 引用文献}

1）上田 真由子他：“特別な呼吸法の事前実施が緊 急事態時の行動を改善させる”, 感情心理学研 究, Vo1. 22, No. 3, pp. 103-109, 2015.

2）且井 伸之介：“リスクマネジメント教育の有効 性評価に関寸る総合的研究”, 厚生労働科学 研究費補助金労働安全衛生総合研究事業 平成 19年度総括・分担報告書, 1-147, 2008.

3）森泉 慎吾他: “エラー体験型教育の効果”, 労 働科学, Vol. 90, No. 5, 171-182, 2014. 